\title{
NELINEARNA ANALIZA VITKIH ČELIČNIH GREDA
}

\author{
NONLINEAR ANALYSIS OF SLENDER STEEL \\ BEAMS
}

\author{
Izabela Šutić*, Paulina Krolo*, Mladen Bulić*
}

\begin{abstract}
Sažetak
U radu je provedena analiza ponašanja tankostjenog hrpta neukrućene zavarene grede na utjecaj jednoliko raspodijeljenog vertikalnog opterećenja. Izrađen je numerički model grede u programskom paketu ABAQUS. Cilj ovog rada je dobiti vjernu numeričku simulaciju ponašanja grede u usporedbi s laboratorijski ispitanom gredom čiji su rezultati ispitivanja preuzeti iz literature te analizirati pojavu izbočivanja u zoni panela hrpta. Provedena je linearna analiza kojom su određeni vlastiti oblici izbočivanja grede te nelinearna analiza kojom su određene vrijednosti deformiranja grede. Na kraju je dana usporedba rezultata dobivenih numeričkim simulacijama s rezultatima laboratorijskog ispitivanja.
\end{abstract}

Ključne riječi: izbočivanje, vitka čelična greda, vlastiti oblici izbočivanja, ABAQUS

\begin{abstract}
The behavior of the slender web plate of the welded unstiffened beam under uniformly distributed vertical load was analyzed in this paper. A numerical model of the beam was created in the ABAQUS program. The aim of this paper is to get a faithful numerical simulation of the beam behavior compared to the laboratory-tested beam whose test results are taken from the literature and analyze the occurrence of buckling in the zone of web panel. Linear analysis was used to determine the buckling eigenvalue of the beam and nonlinear analysis was used to deformation values of the beam. Finally, the comparison between the results obtained by numerical simulations with the results of laboratory tests were carried out.
\end{abstract}

Key words: buckling, slender steel beam, buckling eigenvalues, ABAQUS

*Sveučilište u Rijeci, Građevinski fakultet u Rijeci, Radmile Matejčić 3, 51000 Rijeka
E-mail: izabela.sutic@student.uniri.hr, paulina.krolo@uniri.hr, mbulic@gradri.uniri.hr 


\section{Uvod}

Vitke čelične grede su konstrukcijski elementi koji se sastoje od relativno tankih pločastih elemenata. Budući da poprečni presjeci vitkih greda pripadaju klasi 4, u slučaju kada su tlačno opterećeni u svojoj ravnini mogu se lokalno izbočiti. Izbočivanje je pojava nestabilnosti ravnoteže u elementima konstrukcije koje proizlazi uslijed tlačnih naprezanja koja djeluju u ravnini elementa. Pojava lokalnog izbočivanja u poprečnom presjeku ograničava otpornost presjeka, ali i čitavog elementa na djelovanje uzdužne sile ili savijanja. Konstrukcija ili neki njezin element izveden od tankostjenih elemenata može doživjeti slom zbog izbočivanja pri opterećenjima koja su daleko manja od onih koja uzrokuju slom dosezanjem čvrstoće materijala. Kod projektiranja vitkih čeličnih greda potrebno je dobro poznavati njihova nelinearna svojstva, probleme izbočivanja te gubitak stabilnosti takvih elemenata.

Težnja za primjenom vitkih čeličnih konstrukcija uglavnom proizlazi zbog ekonomskih i tehničkih zahtjeva za smanjenje težine konstrukcije te uvođenja novih materijala visoke čvrstoće. Osim toga, želja za primjenom lagane konstrukcije proizlazi zbog ekonomske isplativosti koja se postiže konstruiranjem u tvornici, prilikom izvedbe konstrukcije, kao i poslije u eksploataciji [1]. Konstrukcije s vitkim elementima koriste se u naftnoj i rudarskoj industriji, konstrukcijama platformi te za mostove velikih raspona. Važno je napomenuti da su grede s vitkim hrptovima, unatoč primjene tankih limova, ipak skupe. Znatan trošak odlazi na izvedbu poprečnih ukrućenja koja se uglavnom postavljaju i zavaruju u radioni. Prednosti primjene neukrućenih greda tj. greda bez poprečnih ukrućenja su jednostavnija izvedba i uporaba automatskih strojeva za zavarivanje radi smanjenja troškova izvedbe [2].

U radu je prikazan numerički model vitke čelične grede, zavarenog Ipoprečnog presjeka, opterećene na savijanje. Cilj je numeričkim modelom što bolje aproksimirati rezultate dobivene laboratorijskim ispitivanjem koje su proveli autori Chern i Kunapongsir, 1973. godine [2] te lokalizirati pojavu izbočivanja u samoj gredi.

\section{Opis laboratorijskog ispitivanja}

U ovom dijelu rada dani su podaci o laboratorijskom ispitivanju grede prema [2], koji su dalje primijenjeni za prikaz numeričkog modela.

Statički sustav ispitne grede je slobodno oslonjena greda ukupne duljine od 3352,8 mm. Na gredi su izvedene ukrute na krajevima i iznad svakog ležaja od limova debljine $19,05 \mathrm{~mm}$. Tlačna pojasnica je bočno pridržana na oba kraja i na trećinama raspona grede pomoću čeličnih kutnika. Na Slici 1 
dan je shematski prikaz laboratorijskog ispitivanja grede. Geometrijske karakteristike poprečnog presjeka grede prikazane su na Slici 2. Vitkost hrpta iznosi 192 (omjer visine i debljine hrpta).

Opterećenje je nanošeno u fazama na gornju pojasnicu grede primjenom šest hidrauličnih preša. Tijekom postupka ispitivanja praćeno je ponašanje u svim fazama opterećivanja na način da su očitanja uzimana prije svake faze. Mjerni instrumenti, korišteni u eksperimentu, su mikroure i elektrootporne mjerne trake. Mikrourama su mjereni vertikalni progibi grede te horizontalni otkloni hrpta, a elektrootpornim mjernim trakama su praćena naprezanja u gredi. Drugi detalji o samom postupku ispitivanja dostupni su u [2].

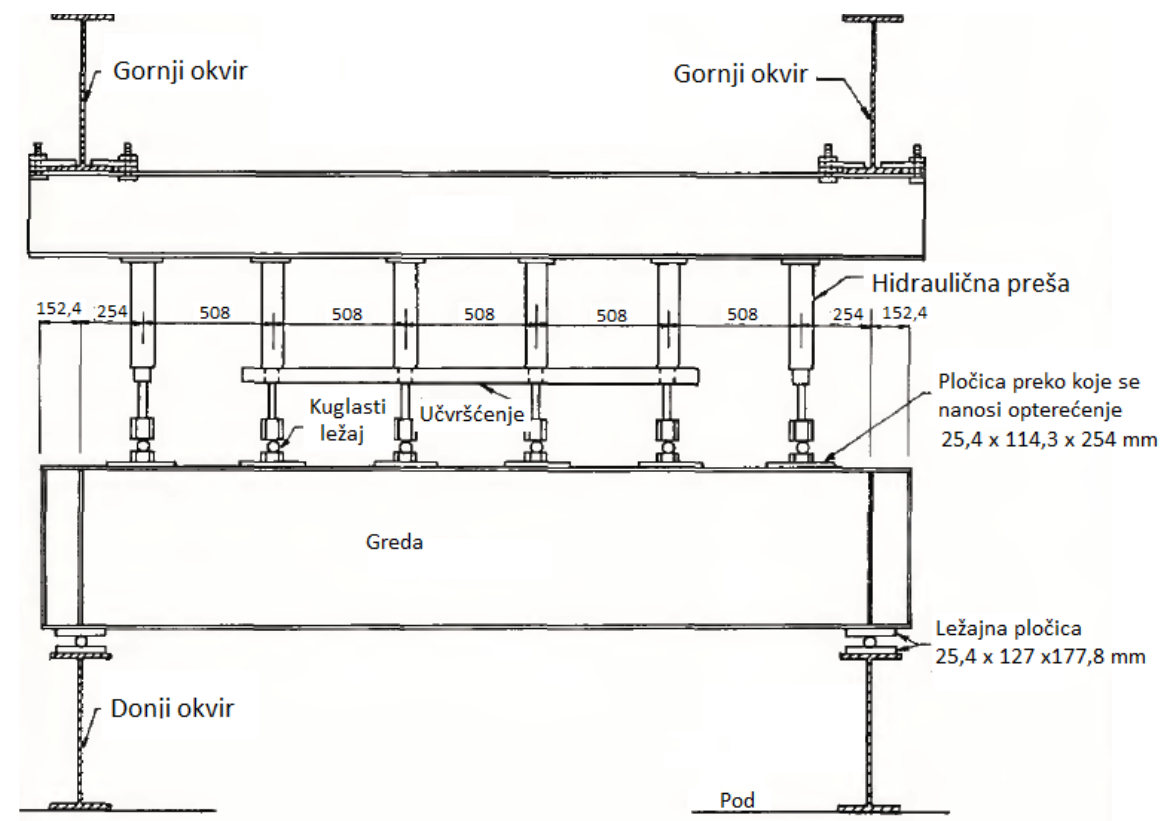

Slika 1. Shematski prikaz laboratorijskog ispitivanja grede [2] 


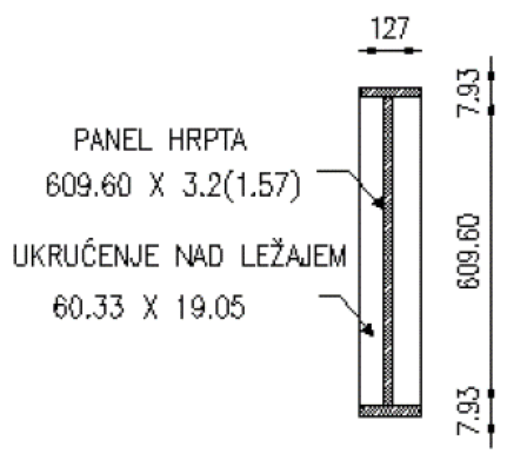

Slika 2. Poprečni presjek ispitane grede [mm] [2]

\section{Numerički model}

U nastavku je dan detaljan prikaz numeričkog modela vitke čelične grede, za što je primijenjen numerički računalni program ABAQUS [3].

\subsection{Geometrija modela}

Poprečni presjek modela grede napravljen je u modulu „Part“. Greda je modelirana primjenom „Solid“ 3D konačnih elementa. Kako bi što vjernije simulirali svojstva laboratorijskog modela grede, pri formiranju numeričkog modela su uzeti u obzir svi detalji na gredi. Modelirane su pločice na gornjoj pojasnici grede preko kojih je nanošeno opterećenje. One dodatno povećavaju debljinu pojasnice i na taj način sprječavaju izvijanje uslijed djelovanja opterećenja. Također su modelirane ukrute na oba kraja grede i iznad ležajeva. Na Slici 3 je prikazana geometrija numeričkog modela grede. Definiranje osi nosača x, y i z; os x: okomita na uzdužnu os grede, os $\mathrm{y}$ : vertikalna os grede, os z: uzdužna os grede.

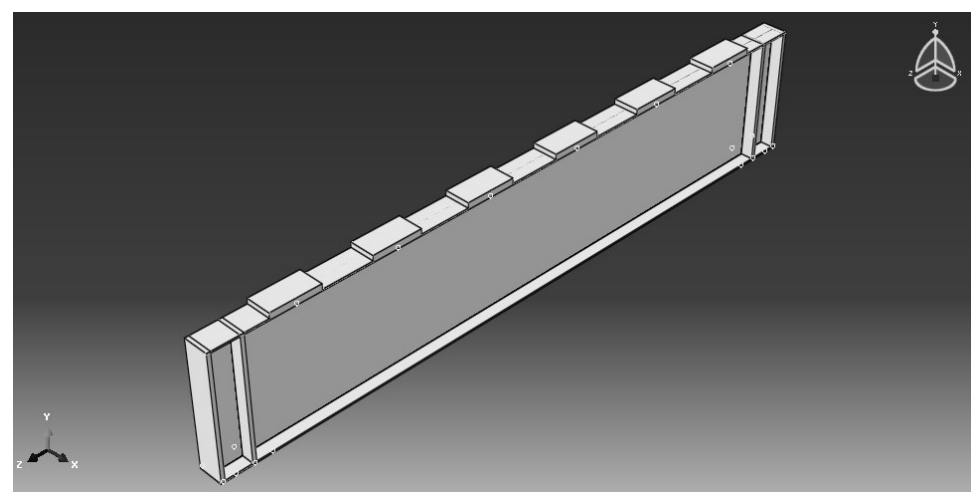

Slika 3. Prikaz grede s modeliranim pločicama i ukrućenjima [3] 


\subsection{Svojstva materijala}

Svojstva materijala se definiraju u modulu „Property“. Greda je izvedena od čelika, a za opisivanje materijalnog modela odabrane su srednje vrijednosti izmjerenih svojstava čelika dobivenih laboratorijskim ispitivanjima. Svojstva čelika dobivena laboratorijskim ispitivanjima približno odgovaraju svojstvima europskog čelika razreda S275. U Tablici 1 dana su svojstva čelika pri čemu su granica popuštanja $f_{y}$, čvrstoća $f_{u}$ te deformacija pri slomu $\varepsilon_{u 1}$ izračunati kao srednje vrijednosti inženjerskih (izmjerenih) naprezanja i deformacija čije su vrijednosti dostupne u radu [2]. Deformacija pri granici popuštanja $\varepsilon_{y}$ određena je $s$ dijagrama iz [2], dok je za deformaciju pri čvrstoći $\varepsilon_{u}$ pretpostavljena vrijednost od 18\%, što odgovara deformaciji čelika klase S275. Ova pretpostavka je uvedena zato što se vrijednost deformacije nije mogla točno definirati s obzirom da su svojstava čelika dobivena nestandardnim ispitivanjem.

Za opisivanje ponašanja čelika u numeričkom modelu grede odabran je trilinearni matematički model. Elastična svojstva čelika su definirana Youngovim modulom elastičnosti $E$ prema izrazu (1), te Poissonovim koeficijentom $v$ od 0,3 .

$E=\frac{\sigma_{y}}{\varepsilon_{y}}$

Tablica 1. Svojstva čelika [3]

\begin{tabular}{|c|c|c|c|c|}
\hline $\begin{array}{c}\mathrm{f}_{\mathrm{y}} \\
{[\mathrm{MPa}]}\end{array}$ & $\begin{array}{c}\mathrm{f}_{\mathrm{u}} \\
{[\mathrm{MPa}]}\end{array}$ & $\begin{array}{c}\varepsilon_{\mathrm{y}} \\
{[\%]}\end{array}$ & $\begin{array}{c}\varepsilon_{\mathrm{u}} \\
{[\%]}\end{array}$ & $\begin{array}{c}\varepsilon_{\mathrm{u} 1} \\
{[\%]}\end{array}$ \\
\hline 286,5 & 419,6 & 0,20 & 18,00 & 36,96 \\
\hline
\end{tabular}

Oznake u tablici 1:

$f_{y}$ - granica popuštanja

$f_{u}$ - čvrstoća

$\varepsilon_{y}$ - deformacija pri granici popuštanja

$\varepsilon_{u}$ - deformacija pri čvrstoći

$\varepsilon_{u 1}$ - deformacija pri slomu

Za opisivanje plastičnih svojstava čelika u programu ABAQUS potrebno je inženjerske (izmjerene) vrijednosti naprezanja $\sigma_{\text {nom }}$ i deformacija $\varepsilon_{\text {nom }}$ transformirati u stvarne vrijednosti naprezanja "true stress" $\sigma$, te stvarne vrijednosti deformacija "true strain" $\varepsilon$. Odnosi između stvarnih i inženjerskih deformacija i naprezanja definirani su izrazima (2) i (3) [4] te su prikazani dijagramima na Slici 4 . 
$\varepsilon=\ln \left(1+\varepsilon_{\text {nom }}\right)$

$\sigma=\sigma_{\text {nom }}\left(1+\varepsilon_{\text {nom }}\right)$

gdje je:

$\varepsilon$ - stvarna deformacija

$\varepsilon_{\text {nom }}$ - inženjerska deformacija

$\sigma$ - stvarno naprezanje

$\sigma_{\text {nom }}$ - inženjersko naprezanje

$E-$ Youngov modul elastičnosti

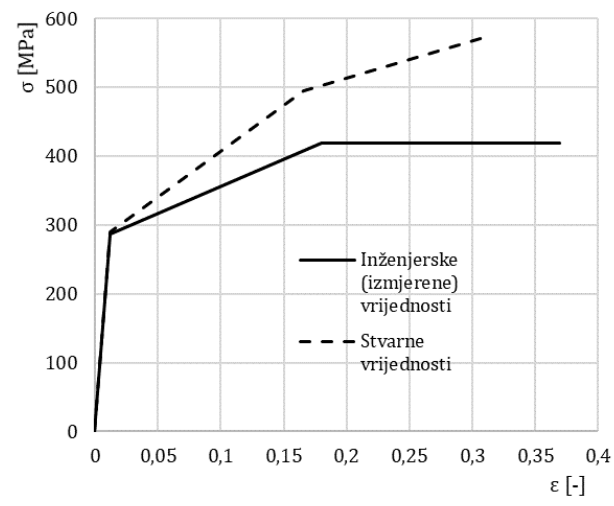

Slika 4. Dijagrami odnosa naprezanja i deformacija $(\sigma-\varepsilon)$ za inženjerske i stvarne vrijednosti

\subsection{Generiranje mreže konačnih elemenata}

Prije generiranja mreže konačnih elemenata, numerički model grede podijeljen je na područja primjenom „Partition“ alata kako bi dobili pravilnu mrežu. Područja su napravljena na mjestima oslonaca, pločica preko kojih se nanosi opterećenje, između pojasnica i hrpta, te između ukruta i grede. Na Slici 5, primjenom modula „Mesh“ i naredbe „Seed Part", generirana je mreža konačnih elemenata. Odabrani su konačni elementi tipa C3D8R, što predstavlja osmočvorne kvadratne elemente s reduciranom integracijom. 


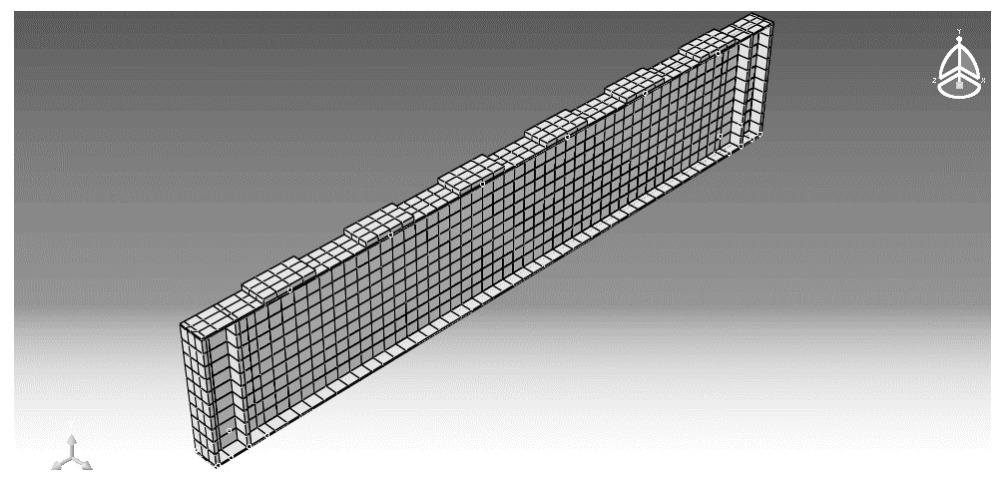

Slika 5. Prikaz mreže konačnih elemenata [3]

\subsection{Definiranje rubnih uvjeta i djelovanja}

U „Load“ modulu definirani su rubni uvjeti grede te djelovanje opterećenja. Primjenom „Set manager“ alata definirani su čvorovi u kojima se definiraju položaji lijevog i desnog ležaja te horizontalna pridržanja, dok su površine na kojima djeluje opterećenje definirane primjenom „Surface manager" alata.

\subsubsection{Lijevi i desni ležaj}

Greda je oslonjena na svojim krajevima na dva zglobna ležaja, a iznad svakog ležaja se nalaze limovi za ukrućenje. Osni razmak između ležajeva je $3048 \mathrm{~mm}$, a razmak od ruba grede do početka ležaja je 73,025 mm. Površina ležajne pločice dimenzija 127x177,8 mm iznosi 22580,6 mm². Definiranje lijevog i desnog ležaja provedeno je u „Load“ modulu. Oslonci su definirani u „Initial stepu“, budući da moraju biti aktivirani prije djelovanja opterećenja. Na ležajevima su spriječeni pomaci u svim smjerovima x, y i z te rotacije oko y i z osi, a dozvoljena je rotacija oko x osi. Dozvoljena rotacija oko x osi omogućuje rotaciju greda pri djelovanju vertikalnog opterećenja.

\subsubsection{Horizontalna pridržanja tlačne pojasnice}

U numeričkom modelu, gornja pojasnica grede pridržana je samo na trećinama raspona, odnosno na udaljenosti od 1123,95 mm u odnosu na rub grede, dok su pri laboratorijskom ispitivanju pridržanja izvedena i na krajevima. Laboratorijski modeli gotovo uvijek imaju nekakav oblik nesavršenosti (geometrijski i/ili materijalni), pa su stoga izvedene ukrute na krajevima greda koje mogu spriječiti moguće prevrtanje modela ili torzijske učinke, dok numerički model nema takve nesavršenosti. Budući da je numerički model simetričan (idealan), prethodno navedeni efekti nisu 
prisutni pa nije bilo potrebno definirati pridržanja na rubovima greda. Horizontalna pridržanja definirana su u „Load“ modulu. U čvorovima koji predstavljaju horizontalna pridržanja spriječen je horizontalni pomak u x smjeru, a dopušteni su pomaci u y i z smjeru te rotacije oko x, y i z osi.

\subsubsection{Zadavanje opterećenja}

U laboratorijskom ispitivanju, koncentrirane sile nanesene su hidrauličkim prešama na površine pločica preko kojih se opterećenje prenosi na samu gredu. U numeričkom modelu je opterećenje simulirano kao pritisak po površinama pločica, što je prikazano na Slici 6.

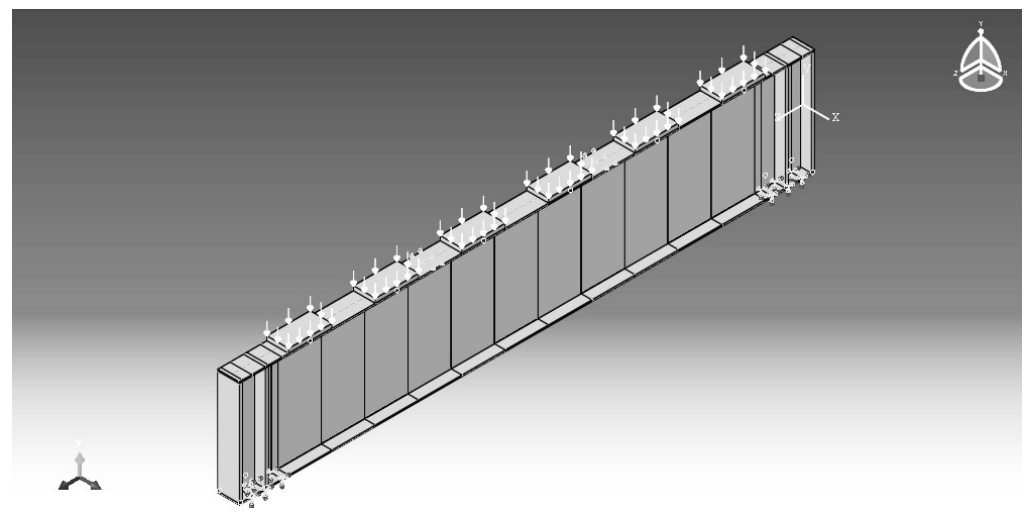

Slika 6. Prikaz simuliranja vertikalnog opterećenja na gornjoj pojasnici grede [3]

U nastavku rada je detaljnije objašnjen postupak provedbe analize ponašanja grede.

\section{Vlastiti oblici izbočivanja i nelinearna analiza}

Nakon postupka numeričkog modeliranja grede (definiranja geometrije, definiranja svojstava materijala, generiranja mreže konačnih elemenata te zadavanja rubnih uvjeta), potrebno je definirati postupak opterećivanja grede tako da se rezultati ponašanja dobiveni numeričkom simulacijom što bolje približe rezultatima laboratorijskog ispitivanja.

Postupak se sastoji od dva dijela. Prvo su određeni vlastiti oblici izbočivanja grede primjenom linearne analize („Eigenvalue buckling analysis"). Definiranjem vlastitih oblika lociramo čvorove na gredi u kojima će se prvo početi pojavljivati pomaci koji prethode pojavi izbočivanja grede. Nakon toga se provodi nelinearna analiza („Postbuckling analysis“) u kojoj 
je potrebno zadati geometrijske nesavršenosti. Ove geometrijske nesavršenosti, kakve je potrebno zadati u numeričkom modelu, ne predstavljaju stvarne imperfekcije grede koje se javljaju u laboratorijskim modelima. Numeričkim modeliranjem stvorene su idealne grede koje nemaju nikakve geometrijske ili materijalne imperfekcije. Kako bi se omogućila pojava izbočivanja grede tijekom nelinearnog proračuna, neophodno je zadati male početne pomake čvorova u kojima će nastupiti pojava izbočivanja u kojima se zadaju tzv. geometrijske nesavršenosti. Čvorovi u kojima će se pojaviti izbočivanja locirani su prethodno provedenom linearnom analizom. Vrijednost geometrijske nesavršenosti zadaje se u postotku debljine lima u kojemu se očekuje pojava izbočivanja.

Kako je prethodno objašnjeno, na površinama pločica je zadano jedinično pritisno opterećenje $s$ namjerom da se dobiju vlastiti oblici izbočivanja hrpta. Na Slici 7 prikazan je prvi oblik izbočivanja grede, što predstavlja oblik mehanizma sloma. Prvi oblik izbočivanja se javlja u hrptu ispod tlačne pojasnice. U lijevom gornjem kutu Slike 7 prikazana je skala vrijednosti horizontalnih pomaka hrpta u x smjeru pri djelovanju jediničnog opterećenja.

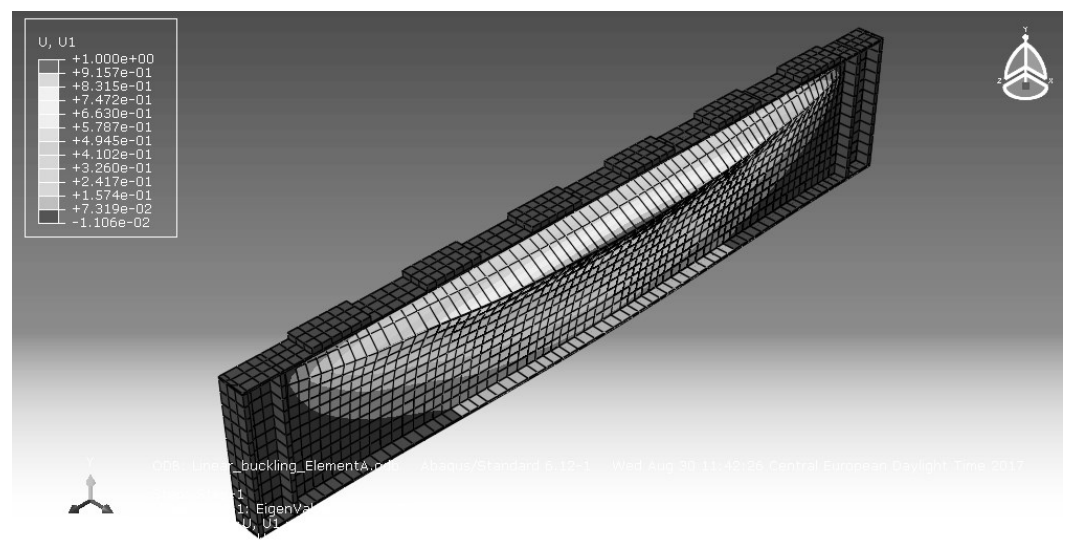

Slika 7. Prvi vlastiti oblik izbočivanja grede [3]

Na Slici 8 prikazan je poprečni presjek grede na sredini raspona. Vrijednosti na Slici 8 predstavljaju horizontalne pomake hrpta grede. Lokalno izbočivanje pojavilo se u hrptu ispod tlačne pojasnice. 


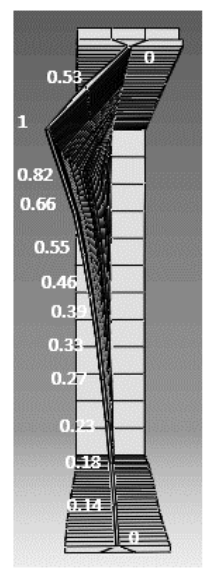

Slika 8. Poprečni presjek grede na sredini raspona za prvi oblik izbočivanja grede [3]

Zadavanje geometrijskih nesavršenosti provodi se definiranjem određenih naredbi u kodu programa. Zadaje se naredba na način kako je to prikazano na Slici 8, neposredno prije koraka u kojem smo zadali provođenje „Static Riks“ analize [5]. Kako bi zadali nesavršenosti prije provedbe nelinearne analize, potrebno je povezati izlazne rezultate linearne analize (pomake čvorova) s kodom za provedbu nelinearne analize. To se provodi na način da se naredbi FILE zadaju izlazni rezultati linearne analize (Linear_buckling_ElementA), koja se izvršava u prvom koraku analize $(\mathrm{STEP}=1)$, Slika 8. Prva brojčana oznaka u sljedećem retku označava vlastiti oblik izbočivanja, a u ovom primjeru zadana je vrijednost 1 budući da nas zanima samo prvi oblik izbočivanja. Druga brojčana oznaka predstavlja vrijednost nesavršenosti i zadaje se u postotku debljine lima. Na Slici 9 je prikazan način zadavanja nesavršenosti koja iznosi $10 \%$ od debljine hrpta, te odabrana vrijednost iznosi $3,20 \mathrm{~mm}$. Kod daljnje analize ponašanja povećavani su postotci nesavršenosti, što je objašnjeno u sljedećem poglavlju. 


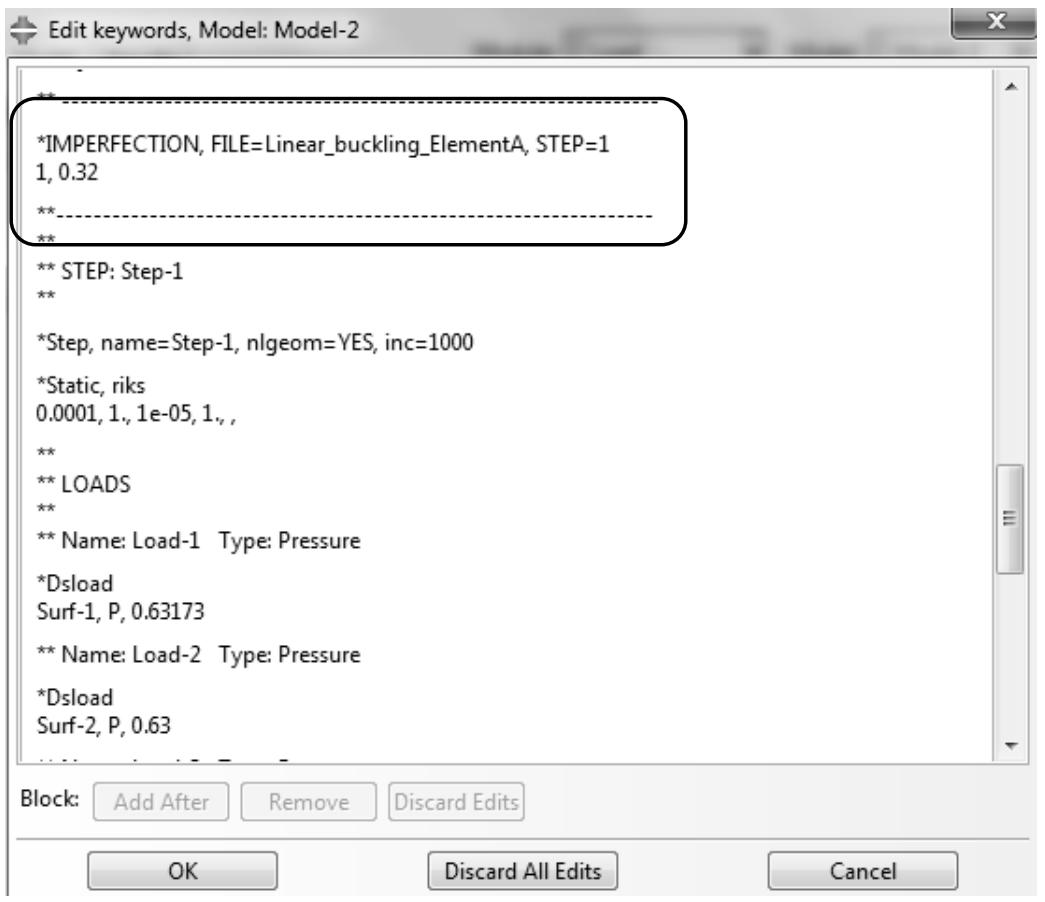

Slika 9. Prikaz koda s dodatkom naredbe za uvođenje nesavršenosti u numerički model grede [3]

\section{Usporedba rezultata laboratorijskog ispitivanja i numeričke simulacije grede}

Laboratorijskim ispitivanjem dobiveni su rezultati horizontalnih pomaka hrpta za granično opterećenje neposredno prije nastupanja sloma grede. Horizontalni pomaci panela hrpta grede na trećinama raspona prikazani su na Slici 10 a). Na Slici 10 b) prikazan je odnos opterećenja na preši P u ovisnosti o izbočenju hrpta grede na udaljenosti od 203,2 mm od donjeg ruba gornje pojasnice. Opterećenje $P$ se nanosilo $u$ fazama opterećivanja. Nisu zabilježena značajna izbočenja hrpta kada je opterećenje na preši P bilo cca 33 kN. Međutim, izbočenje hrpta je ubrzano napredovalo nakon opterećenja $\mathrm{P}$ od cca $53 \mathrm{kN}$, kada se opterećenje približilo graničnom opterećenju pri slomu. 
a)

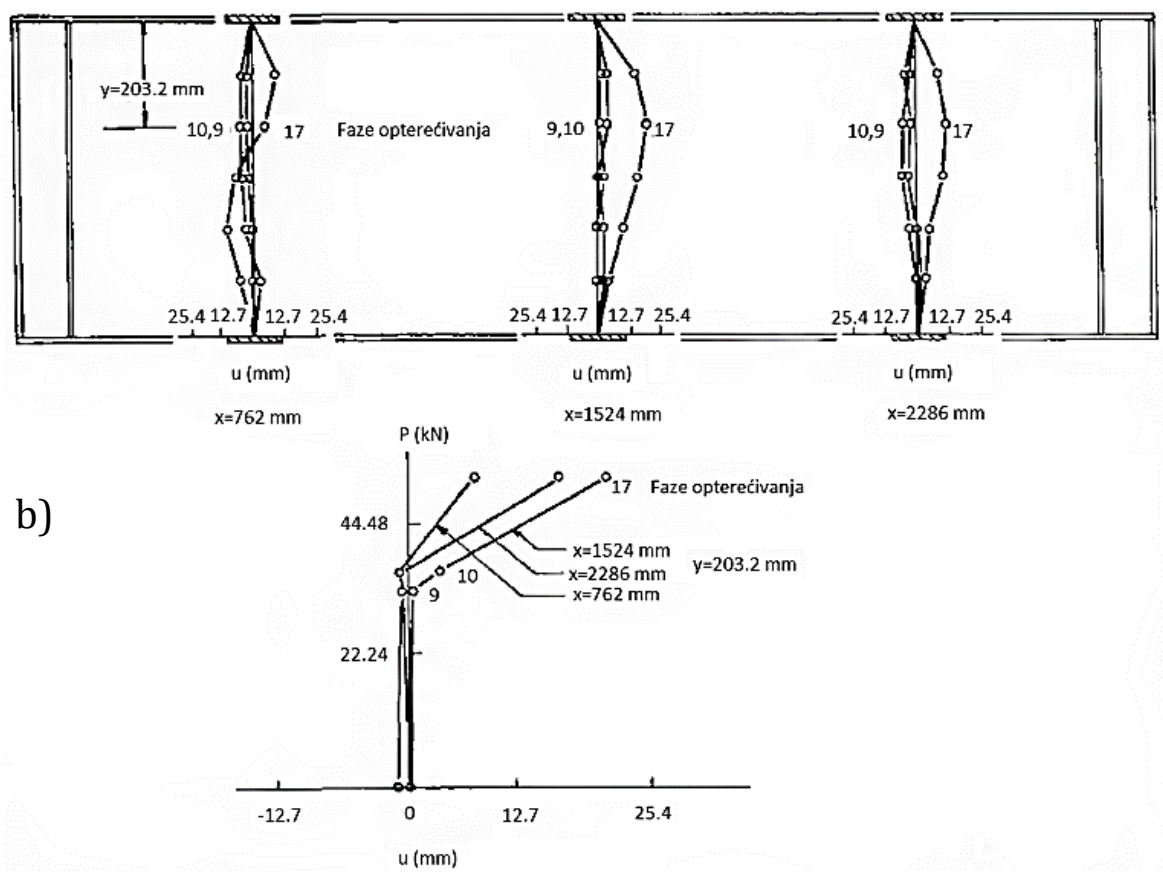

Slika 10. Izbočivanje hrpta grede: a) Horizontalni otkloni hrpta na udaljenostima $\mathrm{x}=762,1524$ i $2286 \mathrm{~mm}$, b) Odnos opterećenja na preši P u ovisnosti o izbočenju hrpta [2]

Pri numeričkim simulacijama grede varirane su vrijednosti nesavršenosti te su dobiveni rezultati uspoređivani s rezultatima laboratorijskih ispitivanja.

Slika 11 prikazuje horizontalne pomake hrpta grede pri zadanoj imperfekciji od 30\% debljine hrpta. Skala horizontalnih pomaka (x-os) prikazana je u lijevom gornjem uglu Slike 11, gdje najveća vrijednost iznosi $17,92 \mathrm{~mm}$ a najmanja $-0,174 \mathrm{~mm}$. Najveći horizontalni pomak se nalazi na udaljenosti $127 \mathrm{~mm}$ od donjeg ruba gornje pojasnice. Vertikalni progib grede na sredini raspona iznosi $5,35 \mathrm{~mm}$. 


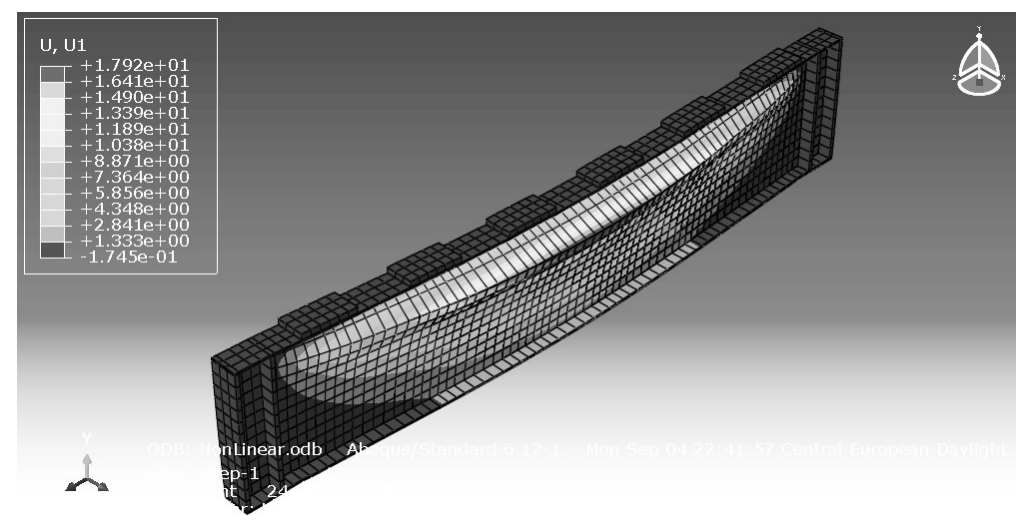

Slika 11. Prikaz horizontalnih pomaka hrpta za vrijednost nesavršenosti od $30 \%$ debljine hrpta [3]

Pri nesavršenosti od $40 \% t_{w}$ horizontalni otklon je manji, a pri nesavršenosti od $30 \% t_{w}$ horizontalni je otklon veći. Greda s početnom geometrijskom nesavršenosti od $30 \% t_{w}$ daje najbolju podudarnost $\mathrm{s}$ rezultatima laboratorijskog ispitivanja (Tablica 2). Horizontalni otklon hrpta grede dobiven numeričkom simulacijom se pri nesavršenosti od 30\% debljine hrpta $t_{w}$ razlikuje za $0,78 \%$ od horizontalnog otklona hrpta dobivenog laboratorijskim ispitivanjem. Vertikalni progib grede dobiven numeričkom simulacijom se pri istoj nesavršenosti razlikuje za 12,15\% od vertikalnog progiba dobivenog laboratorijskim ispitivanjem. Razlika između rezultata položaja najvećeg horizontalnog pomaka moguća je zbog primjene gustoće mreže numeričkog modela koja se razlikuje od veličine rastera na kojima su bili postavljeni uređaji pri laboratorijskim mjerenjima pomaka. Osim toga, nepoznavanje svih relevantnih svojstava materijala iz eksperimenta utjecalo je na neprecizno definiranje parametara materijala u numeričkom modelu, što je također moglo utjecati na dobivene rezultate.

Tablica 2. Usporedba laboratorijskih rezultata s rezultatima numeričkih simulacija [3]

\begin{tabular}{|l|c|c|c|c|c|}
\hline \multicolumn{1}{|c|}{ Parametri } & \multicolumn{4}{|c|}{ Numerički rezultati (mm) } & Laboratorijski \\
rezultati (mm)
\end{tabular}




\section{Zaključak}

Laboratorijskim istraživanjem neukrućene grede $\mathrm{s}$ tankostjenim panelom hrpta dobivene su informacije o ponašanju hrpta grede pod utjecajem jednoliko raspodijeljenog opterećenja. Numeričkim modeliranjem grede nastojali smo simulirati rezultate dobivene laboratorijskim ispitivanjem te analizirati pojavu lokalnog izbočivanja u pojedinim elementima grede.

Rezultati dobiveni numeričkim simulacijama grede pokazuju vrlo dobro podudaranje s rezultatima laboratorijskog ispitivanja. Pri laboratorijskom ispitivanju došlo je do nesimetričnog izbočivanja na lijevom i desnom kraju grede na prvoj i zadnjoj trećini raspona. Zbog simetrično postavljenog opterećenja i simetrično postavljenih rubnih uvjeta, u numeričkim modelima očekivano su dobiveni simetrični odzivi greda pod utjecajem vertikalnog opterećenja. Do pojave nesimetričnosti rezultata koji su dobiveni laboratorijskim ispitivanjem došlo je zbog moguće nesavršenosti koja je nastala pri postavljanju grede tijekom ispitivanja ili geometrijskih i materijalnih nesavršenosti. Razlika između rezultata laboratorijskog ispitivanja i numeričke simulacije je vidljiva i na mjestu pojavljivanja najvećeg horizontalnog otklona hrpta, što je moguće zbog različito definirane mreže na laboratorijskom uzorku na kojima su mjereni pomaci i gustoće konačnih elemenata na numeričkom modelu. Na laboratorijskom uzorku, mreža na hrptu je imala pet vertikalnih podjela dok je mreža konačnih elemenata u numeričkom modelu bila podijeljena na dvanaest vertikalnih segmenata po visini presjeka grede.

Izbočivanje je pojava koja može uzrokovati nagli slom konstrukcije, što dovodi do potencijalnih ekonomskih gubitaka, čak i gubitaka života. Važno je razumjeti ponašanje izbočivanja ako proračun uključuje vitke konstrukcije izložene tlačnom naprezanju, a to su obično velike čelične konstrukcije mostova, platformi i drugi građevinski objekti.

\section{Literatura}

[1] M. Čaušević and M. Bulić, STABILNOST KONSTRUKCIJA, Zagreb: Golden marketing - Tehnička knjiga , 2013.

[2] C. Chern and V. Kunapongsiri, "Experiments on Unstiffened Thin Web Girders," Welding research supplement, pp. 159-167, 1973.

[3] Šutić I. "Nelinearna analiza vitkih čeličnih greda. Sveučilište u Rijeci. Građevinski fakultet u Rijeci. Diplomski rad. Rijeka. 2017.

[4] ABAQUS, "Getting Started with Abaqus Interactive Edition, Version 6.12","Dassault Systemes, Providence, Rhode Island, USA, 2012.

[5] ABAQUS, » "Analysis User`s Manual I_V, Version 6.12",« Dassault Systemes, Fremont, Calif, USA, 2012. 